\title{
EDUCATION SITUATION IN ZANZIBAR
}

\section{Ramadhani Issa Hemed ${ }^{1}$}

doi:10.5937/Oditor1901032H

Pregledni rad

UDK

$331.101 .262: 37(678.1)$

005.961:005.336.1

\section{Apstrakt}

This paper showcase the Educational situation in Zanzibar, soon after the attainment of independence up to date, this article is divided into two parts, first part is discussing the historical background of education system before and different steps that the education sector has made up to the year of 2018, also this part will try to illustrate the educational structure of Zanzibar with its motives for Zanzibaris and National development.

At Last there is a second part that discusses some crusual issues which are vital in discussing educational situation in Zanzibar such as Enrolment of students in both levels of education, socio-economic context, quality and efficiency of education in the society, school's facilities, quality of human resources recruited and infrastructures, financing, and lastly access to education.

After discussing these issues this papers will over look on the improvements and strengthness of Zanzibar Education compared with other countries in East Africa, challenges that facing Zanzibar Education and the suggestion up on the discussed issues.

Key words: education, Zanzibar, economy of public sector

JEL: $A 20$

\section{Introduction}

Zanzibar is comprises two main Islands which are Pemba and Unguja, and a number of sparsely populated smaller islands, all in which make up a total area

\footnotetext{
${ }^{1}$ Ramadan Issa Hemed, bachelor, University of Der es Salam, Tanzania, Mwalimu Julius Nyerere Mlimani Campus, P.O. Box 35091, Dar es Salaam Tanzania, ramahchonde2794@gmail.com
} 
of 2,693 Square kilometers. In the year 1964 Zanzibar form the union with Tanganyika and became The United Republic of Tanzania. In this union there are Union matters which both Zanzibar and Tanganyika shared together such as Defense affairs, External affairs, monetary issues e.t.c but Education is the one among non-union matters, consequently the Responsibility for ensuring education development falls under the Responsibility of Zanzibar Government (Ministry of Education \& vocational training 2006).

Educational situation before independence; Zanzibar as other countries of Africa has attained its independence around 1960's, and education condition before these year was in worse condition which were characterized by racial segregation, classes in acquisition, and Expenses hence most of African children by that time did not managed it due to the mentioned factors.

Educational situational after independence, soon after attaining the independence 1964 the Zanzibaris started to Overcome the previously situation and during the year of 1986's the Revolution government of Zanzibar proclaimed free Educatuon for all Zanzibaris, for both pre-primary school and primary school education level regardless of color differences and Gender. From this time Zanzibar's education has undergone different changes in Advancements and Improvements, example different policies and amendments has made so as to copy with the international demands and declarations for the education development. For instance in 1991 the government issued the Zanzibar Education Policy which articulated key sectoral objectives and targets that as a Nation are expecting to achieve, however that document amended in 1995 following the pronounced of international conventions and declarations like that of 1990's Jomtien Declaration on education. But also on 1996. the government issued the Zanzibar education master plan (ZEMAP) which specified the goals and objectives of Zanzibar's education for the next ten years. (Abdalla, 2014)

\section{Education structure}

Most of African countries Zanzibar included have education system and structures which do not adequately reflect the country's social demands, since its graduates are not fit in the International employment market because the 
structure is keeping learners too long in the school and produce oriented more towards work in the urban modern sector and white color jobs for example before 2006's reshuffle of education structure, the structure was like this; Primary education duration was seven (7) years consecutive, the secondary level which has two channels, one which is subdivided into first cycle of three years (3) and second cycle of two years(2), and the other of full uninterrupted secondary cycle of four years(4), this means that both of these mentioned steps leads a student into a high school level of two years(2) consecutive. But after the reshuffle of policy the education structure changed then set an specific entry years old for pupil's and reduced school time durarion, hence the structure became of Pre-primary level that recruiting children between the age of 4-5 years, Primary school that takes children for six years, Ordinary secondary education that enrolled children of age around 12-15 years old for four (4) years and Advanced secondary school for two (2) years consecutive, and for those who passes at this level are chosen to join up University level. From Primary to Secondary level is the compulsory Education that every child must passing through it.

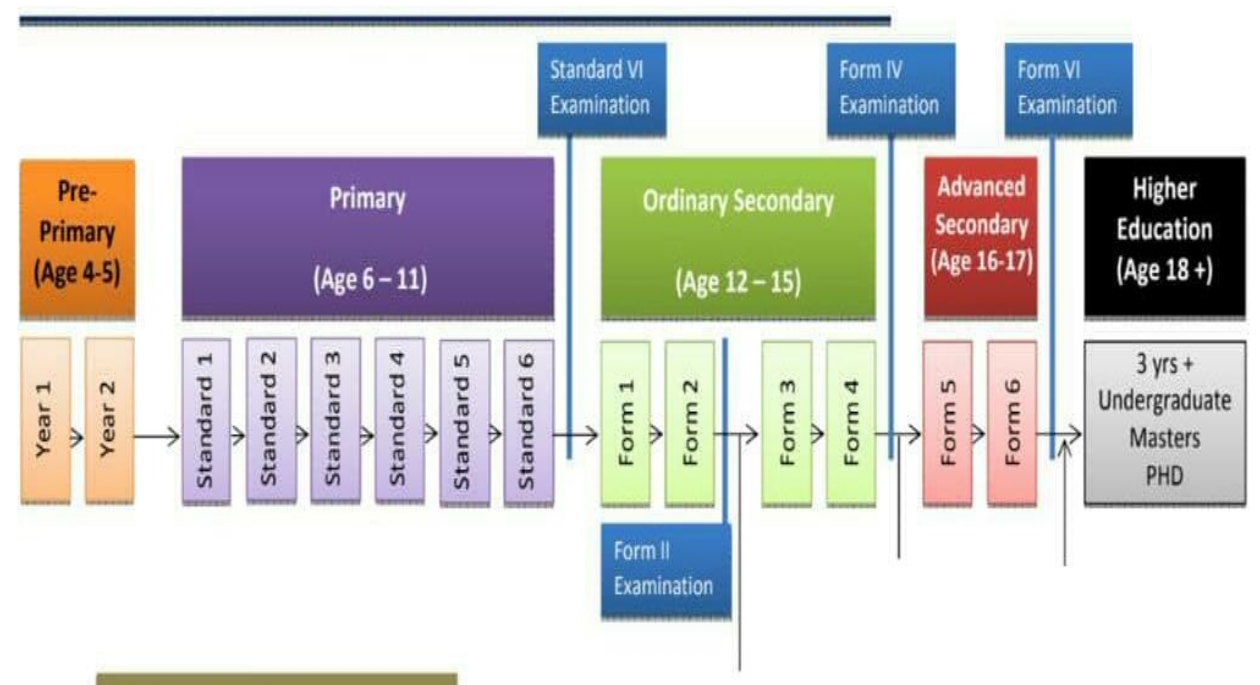

Adult Education Programmes

Picture 1: Structure od education in Zanzibar 
The strength of this new education system is that, It offers the enrolment of children in a right time or age at school (4-5) yeas old hence it facilitates the easily adaption of school environment and development of mental ability, but also this structure enabling pupil to finish their studies at the on right time compared with that one provided in Tanzania mainland where standard one pupil is compulsory to be enrolled at the age of seven (7) years old and finished primary level with 14 up to 15 year. But the challenge of this system is that it has too many barriers such as final exams which is used as a measurement for students who Qualify to continue in the next level or class, this system lead to other students to quit studies after when they failed because the policy demands them to repeat the same class in the next academic years or to discontinue with next classes, example in standard six and form two national examinations. Also the system is still creating spoon feeded graduates since there is a sequence of more than seventeen (17) years of sitting in the school consecutive without learning any other skills apart from school subjects, such as technical skills and handcraft activies, therefore every graduates is has that employed mentality.(MoEVT, 2010).

\section{Socio-economic context}

Here the discussion is on how socio-economic context of Zanzibaris affect and reflecting the education situation in Zanzibar. In this islands its people are that of lower status in economic and who earn almost one 1 USD per day income, and their main economic activities are fishing, small businesses and tourism for the few who have an access for it (those who have enough capital), the population growth rate of these people are estimated to be $2.8 \%$, population percentage around (0-14) years old is $42.5 \%$, (this is a group of students), unemployment rate $4.4 \%$ and the youth unemployment rate is $17 \%$, therefore through this data it tries to clarify the number of students in school and those who are out of schools is bigger number related to the national pupulation and badluck there is also a big number of youths who are unemployed and some of them they have completed probably Primary level, secondary level or even University level.

From this point it is true that even the rate of parent who is capable and committed to give school equipments constantly such as books, shoes and meals 
for their children is low, due to their level of economy and actual amount of their capital income. Again in Zanzibar most of primary and secondary schools especially those which owned by the government are the day schools, hence children are supposed to go and return home for a meal everyday of their school life, that situation hinder the advancement of education in this country, since sometimes pupils does not return back to schools and misses the rest of classes periods at school,due to different reasons such as hungry because of absence of food at their home or due to the long distance to walk from their school to home.

\section{Financing education sector}

The government of Zanzibar is fully committed on financing and facilitating education sector since it is the Government's responsibility according to the educational policy, the government suppose to allocate and set enough budget on education sector, however there is some logical notions that the budget of education in Zanzibar which is always proclaimed in annual budget does not correlate with the actual output for the student's result, therefore is it clear that there is mis-allocation of funds in important areas of education sector, also poorly supervisions on utilization of funds in accordance areas, that is why the impact is also follows down.

For instance it is very common to see students in the class of thirty students uses only six text book for learning in a particular subject or there is only one book for a teacher due to the scarcity of books in school, this leads to the poor performance of students in their daily school performances and even in their final exams, also in Zanzibar's schools it is very common to the class to have a big number of student in one class room,which is possibly leads the teachers fail to make an follow-up for every student's development and the last challenge concerning this field of financing is on teacher's interest, teachers in government schools has no motivations of hard working due to the inadequate housing services for them and law salaries; despite of all these challenges in financing but the government is still keep on resolving some issues like desks and books for students through the annual government budget, internal aids and NGOs supports. 


\section{Efficiency of education}

According to the 2006 Education policy "the government shall ensure that all primary school age children are enrolled at the age, remain in school in full attendance, perform well and successfully complete primary education." This target has not yet achieved for instance in 2013 the end of primary education rate was $80 \%$ rather than $100 \%$ which targeted by the policy, this is due to the different reasons such as pupils fails their final exams, involvement in drugs abusing, pregnant for girls pupils and others are left the school due to the family inability on taking care of them and direct supervision on pupil's progressive. Also in secondary level some form two students do not completing their education because of failure in the form two national examinations. Despite of all of these insufficiency on Zanzibar's education but it is still in the leading lane amoung Nations in East Africa, Zanzibar has some efficiency education especially in primary level; For example the table below shows the comparison of six countries which fund in East Africa in 2009 -2010 except Kenya which its data was not recorded.

\begin{tabular}{|l|lc|cc|}
\hline & \multicolumn{2}{|c|}{ Primary Survival Rate } & \multicolumn{2}{c|}{ Primary Completion Rate } \\
\hline Zanzibar & 80 & $(2012 / 13)$ & 80 & $(2012 / 13)$ \\
\hline Burundi & 44 & $(2011)$ & 62 & \\
\hline Mauritius & 97 & $(2011)$ & 99 & \\
\hline Rwanda & 36 & $(2011)$ & 58 & $(2011)$ \\
\hline Tanzania (overall) & 81 & $(2009)$ & 81 & \\
\hline Uganda & 25 & $(2010)$ & 53 & \\
\hline $\begin{array}{l}\text { Source: World Bank Database } \\
\text { 1. Unless otherwise specified }\end{array}$ \\
\hline
\end{tabular}

Picture 2: Efficiency education in Zanzibar

Apart from the primary level which is seen as it has almost $80 \%$ of efficiency in education but in the secondary level zanzibar's education is still ineffiency, because most of the students does not completing their ordinary level education due to poor perfomance in form two national exams and the worse results of form four national exams hence the transition rate from two to three, and that of form four to five (V) is currently unstable and mark the point of inefficiency in secondary education level which does not meet the policy's target, and in these 
level some students are completing one level to another one with incompetence on different angles of academic such as reading and speaking fluently English which is a language for instructions in secondary level,dependable mind and poor exhibition in reaoning capacity.

\section{Access to education}

Education accessibility in Zanzibar is tends to rise year after year due to good policies of education such as free provision of pre-primary and primary education, availability of private schools and colleges which are providing education with reasonable costful(Kisić, \& Petković, 2019)., presence of many schools around people's residential areas, provision of facilities for teaching and learning process, also the government of Zanzibar has good system for enrolling too many students per academic year and managing them in providing education than private sectors which is good thing because its education is affordable than that of private schools. Example the following table below is showing the enrolment of students in all levels of education from pre-primary school to secondary education in urban and rural areas in Zanzibar in last ten years for both private and government schools.

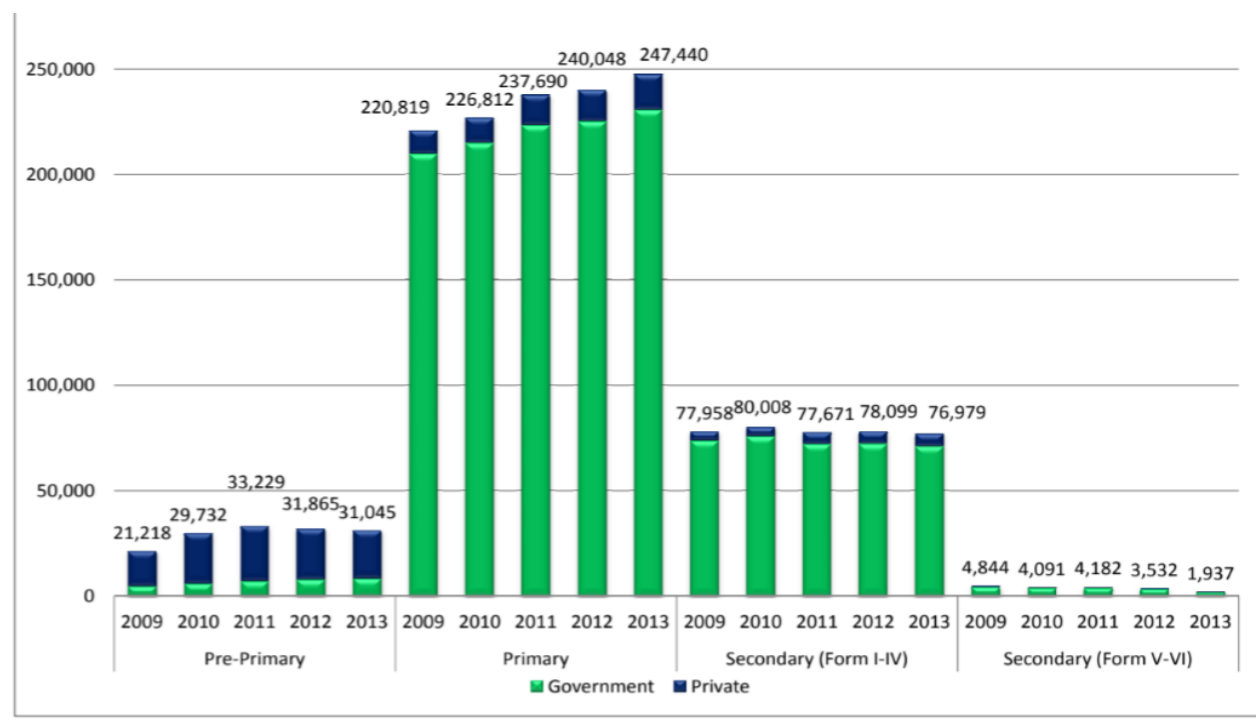

Picture 3: Education in private and government schools in Zanzibar 
Therefore as the graph above shows the government schools are leading the number in the enrolment of students, this justifies the seruousness of the government on making sure that every child must have the pre and primary school education as compulsory education and must be free from costful as documented in the the National education policy.(Jovanović, \& Jovanović, 2018)

Enrolment of students with special needs; According to the 2006 education policy which states that "inclusive education shall be promoted to ensure that children with special needs get equal opportunities, barriers to learning are addressed and the diverse range of learning needs is accommodated" in monitoring this policy and making sure the accessibility of education for all children is achieved, therefore physical disabilities of one's children should not be the barrier for her or him to attain the right to be educated, hence were purposely programmes for the sake of to meet this policy, therefore in Zanzibar there are schools with condusive inflastructures for disabled pipils to be enrolled,but again all governlents and private schools are required to have atleast favoured conditions that can accomodate pupils with special needs,also the government has that tendency of recruiting specialized teacher for students with usual impairments, hearing disability, and intellectual disability and mixed to meet the demands of students.

Also there is enrolment in adult education; this meaning that even the adults who did not attended primary school education are given chance to get education, this programme aimed at reducing the illiteracy rate in the country but also there is enrolment of students in technical education and other alternatives education for the sake of removing ignorance for its people, therefore Education in Zanzibar is accessible for every group of its citizens.

\section{Quality of education}

The quality of education in Zanzibar it not such good as other African countries, because it is inherited from colonial education that does not meet the current international standards and needs of modern world, this is seen through the graduates who are not competent and cannot exhibit their ability of doing things by their own with the perfections and to using classroom knowledges in actual 
context, that is why the primary students the only thing they have in their mind after completed primary level education is to join form one, the same applied to the form four students who expecting to joining the form five and there after joining up University but not thinking on basing in a technical colleges or hand craft activities. The foundation of this mentality is due to the education's syllabuses and the curriculum that does not put much emphasis on technical subjects, science subjects and handcraft working, rather it emphasize much on Unrealistic subjects such as history, Arabic and language studies which hinder the possibility of students to exhibit their exceptional abilities on doing and innovating different things.

See the following figure that shares the standard seven (VII) pass rate in three subjects 2010-2013.

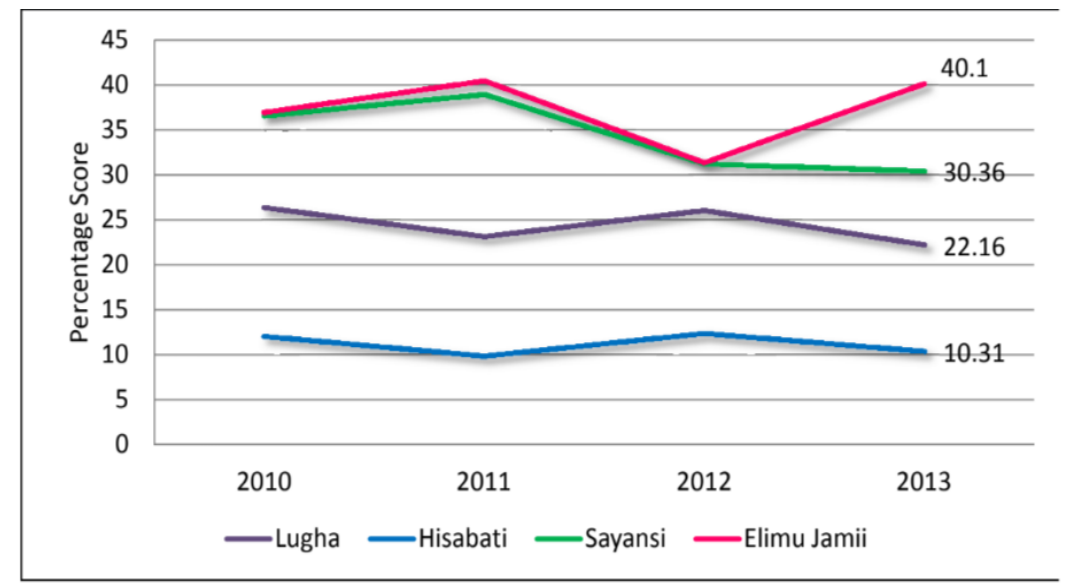

Picture 4: standard seven (VII) pass rate in three subjects 2010-2013

The above chart shows how students perfoming well in social studies and fails in science, English language and mathematics, this reflect the how the teachers put emphasis on subjects which does not give a chance to exhibit his or ability in perfoming and creativity.

\section{Social facilities}

This section presents information on how the availability of various facilities by level of education in Zanzibar Education, the government has its own target 
relating to provisions of school facilities so as to ensure that every school should have all important accessories related to succession of teaching and learning process, it aimed to increase the sustainable and appropriate water supply in the school, sanitation and hand washing facilities like dishes and soap around school areas including toilets and in class rooms, again the government insisted every school should have a library or resources centre for education achievements, also the education policy of 2006 stipulated that ICT should be included in the curriculum at all level, expand ICT infrastructures that coverage in schools and communities and the last one is school every school shall often diverse sports and physical education facilities. But the reality of these Government targets and education policy's requirements are not achieved in $100 \%$ especially in government schools, unlikely in the private schools there are a plenty of facilities in the school compounds such as libraries with fully of userble books, laboratories with enough equipments for experiments, sustainable water supply and special facilities for sports, games and physical education which enhance the availability of sustainable and tangible education.(Suckall, Tompkins, Stringer, 2014)

Pre- primary facilities In this level of education, the government schools are not doing well, since the private schools has invested much in primary education, for example in pre-primary schools the pupil's latrine ratio is bigger than that ratio within the schools government, also in government schools pre-primary students are divided into two shifts, the morning shift and the afternoon shift due to the absence of classes and facilities like desks for children. (Stankić, Jovanović-Gavrilović, \& Soldić-Aleksić, 2018)

Primary school's facilities. In the primary level education facilities does not differs much with that of pre-primary level especially in the government schools, such facilities like the ratio of pupil's latrine, and learning materials in the classroom, like books, and other learning aids are in unevenly distributed, again even the number of desks and chairs are not rationally meet the requirements with the actual number of the students enrolled in a particular class, as it is clear that the population rate tends to increase every year therefore even the number of enrolled students in primary is increases every year but facilities does not match the rate of pupils enrolled per year. But this situation 
is may seemingly stranger in the private schools where it has enough budget for schools facilities and strong supervision on the allocation of money or facilities input, such as in buying classroom appliances there is direct supervision, other learning and teaching material and teaching materials are accessible accordingly depends with the actual number of the students recruited in standard one.

Secondary level education facilities. This part it describes how the government sets its goals on making sure there is enough facilities in secondary education and the realistic situation in the schools, here the government of Zanzibar through educational policy of 2000, 2006 and that of 2016 all of them are insisting accessibility of different school facilities such as enough water and reliable for all the time when students will be at school, enough toilets for students that meet the actual demands of all students (including disabled students), enough ratio of books and other learning materials, and availability of laboratory with its apparatuses in secondary schools, the government is struggling to ensure all the above goals achieved in $100 \%$, however there are some challenges in the schools like absence of enough latrine, laboratory for science subjects and its equipments, again there is no constant ratio of books and desks for the students due to inconsistency of students number in the new academic year enrolment the rising and falling.

\section{Quality of human resources and infrastructures}

In educational sector the quality recruitments of human resources such as teachers is the very important key to its development, this is due to the reasons like once teachers are incompetent then they will produce graduates who are not competent and viceversa , therefore in education the first thing to consider before the enrolment of students is to make sure that a school have enough and qualified teachers so as to give the Quality education and brings out better results, but failure to do so there will be a possility of having graduates who are not much competent; see the data in the year 2013 as case study, shows private recruitment of teachers and government, on the Government side had recruited more than 10,000 teachers in its schools, and some of them were untrained, certificate, diploma and degree as following pre charts shows. 


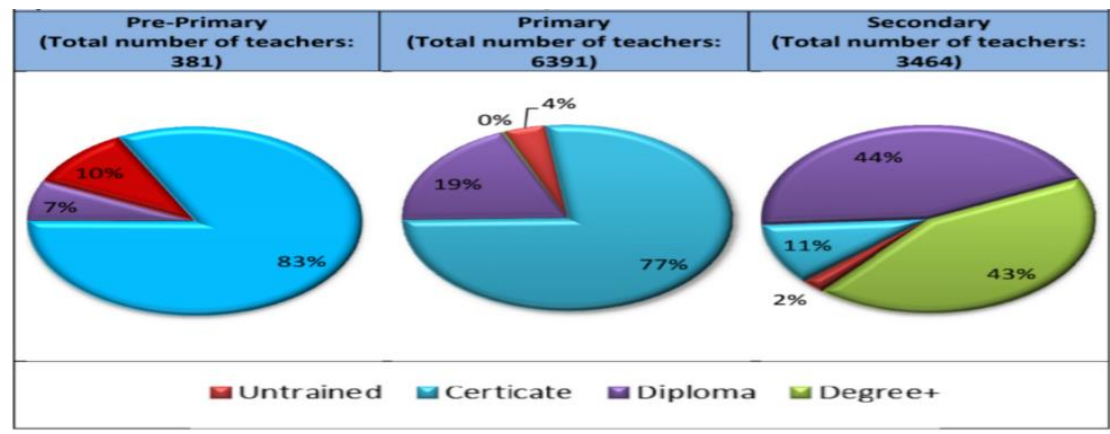

Picture 5: Education structure of teachers in schools on Zanzibar

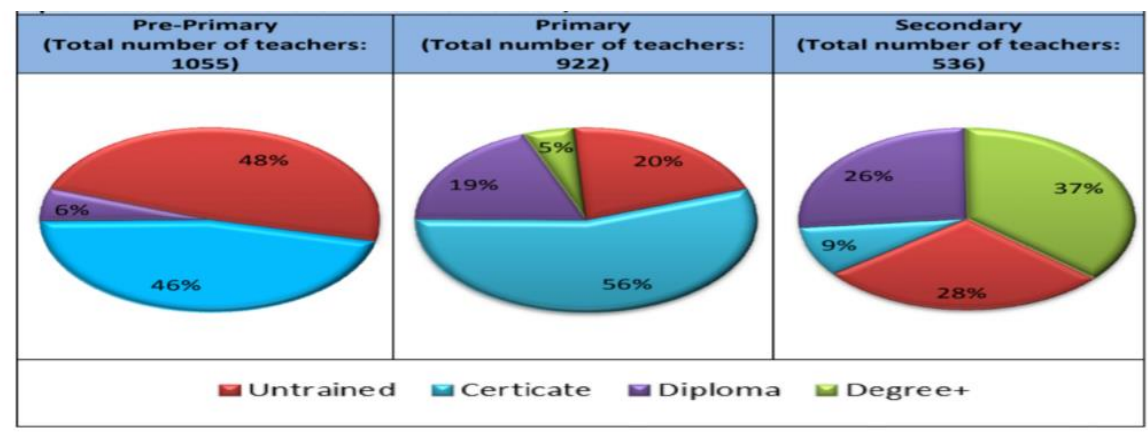

Picture 6: Number of teachers in education system on Zanzibar

The above charts shows that the government tried for its level best to employ teachers with quality and who can be helpful in giving out quality education as well, but there is challenges in this like recruiting untrained teachers to teach students hence they giving out unacceptable education and that of no Quality; But this has revealed twice or even thrice in the private schools whereby within the same year of 2013 they had almost 861 untrained teachers out of 2513 the total number of all teachers for pre-primary, primary and ordinary level. This shows to what extents there were poor recruitments conditionality's for teachers in private schools especially in considering the quality of teachers, education level and they did not fore look the kind of services that will be offered by those teachers (untrained) to students.(Hija, 2010; Ignjatijević, Cogoljević, \& Milenković, 2018) 
Infrastructures in education; in general the physical and social infrastructure are good, since there is presence of classrooms for guiding and counseling the students, hospital nearby the school surroundings, accessibility of food and water nearby or within the school areas which help students sometimes not to loose a period from school due to absence of meal nearby, also accessibility of transport especially school buses for the private schools and few governments schools, also public transport like buses which is less costiful and has good rules for student's fare,that they pay a half of Adult's fare,this has enabling many parents to afford taking their children to school instead of letting them to walk for alot of miles to scholl. But the challenge in infrastructures is absence are domitories in most of government schools and hence some students supposed to walk for a lot of meters to go at school hence coming late or tired and sometimes to use a transport which is costful for them, another one is there is no enough houses for teachers, which lead them to rent a house in far away areas from the school then coming late at school ot to use a public transport or to walk in a very long distance up to school.

\section{Current situation}

The current situation In Zanzibar education is passing through transition where by there is still unstability in the efficiency of primary education and in secondary education, since the number of students which enrolled in primary school does not matching with the number of those who joins in form one, also there is a high rate of form four who fail their final exams and therefore the number of student enrolled in advanced level (form five) is insufficiency number same applied to the students who selected to join at Universities and other colleges.(MoEVT, 2006)

Despite of the current education situation to be in path way or transitions time but it is still seems has improved compared with previous years, this is due to the fact that even the number of universities and colleges are increases and the enrolment of students in every year tends to be in good ratio,that is to say the efficiency of education in lower level is in high rate then the policy's objectives is met and the demand of higher education level provisions,although alot of effort has made in education for the sake of making it better but its still the type 
of education that is provided today in Zanzibar does not fit the current world's demands that covered by the advancement of technologies and science; it is known that the current world needs much graduates who are capable of innovating new things, and who can be mentally independent instead of dependant being employed. Also there is a scarcity of directly employment for graduates from different levels of education, such as form four leavers, form six leaver and even undergraduates, then it kills motivations for young scholers especially in primary and secondary students on putting much efforts in education since they are already have sub-conscious information about unemployment situation in government and in private sectors even if after completed their studies and passed well.

\section{Challenges of education in Zanzibar}

In the structure of education the challenges are, there are too many barriers for the students completions their compulsory education that in pre-primary education,primary education and secondary education because of the education structure; for instance the presence of the standard six national examination that required those who passes the exams to continue with form one (secondary education) and for those who fail the exam are sent back home (discontinues) with the studies hence it reduces the number of children to acquire one of the the compulsory secondary education but it is due to the examination that create a differences between those children who acquire the secondary school and those who do not have it and then creating a group of street children. Also there is form two examination which is also require the children to pass national examination so as to continue with form three, and those who failed examination suppose to reseat the class for the next year the system does not give a second chance for the students to retry and exhibit their ability, also most of the students who failed their form two examinations Quit the school and leave studies because of shame and feeling that they are not good enough compared to others (passed exams) hence reduced the number of completed students in school, this hinder the chance for policy implementations, which states that education for primary level and secondary level is compulsory for all Zanzibaris children. 
Social influences: on this part the discussion is on how the society and community challenging or motivating the development of education in Zanzibar. Education situation is determined in its failure or in its advancemen, but in both these dimensions the society should be a vital catalyst for whether improvements or failure of education in a particular country,since it happens sometimes the society act as an influence for the underdevelopment of education,may be in school constructions participations if the society will not be active then the project will automatically experience hardship,also on isues like drug abuses and involvements of adult in love affairs with pupils, and such issues related to, for instance in Zanzibar's community there are problems in different areas that act as a effort to pull down the education advancements such as in enrolment of pre-primary school not every parent send his or her children to school,since other parents retains their children at home or taking them to Arab schools instead of pre-primary school which is compulsory by the government policies. Also some of the parents are taking directly their children to primary school class before attending pre-primary school which prepares a child for a primary school hence children are finishing the primary level while are not competent in some subject such as mathematics, English, and science subjects because they lack preparation and basic foundation during the preprimary education, also the society has failed to monitor and strictly supervision of their children after school hours hence children involves in drug abuse.

And therefore the number of students whom quit the studies because of social influences and failure of parent stop student's misconducts.

Financial problems, Zanzibar as other African countries does not put much emphasize an Education in the Government annual budget, due to this in Zanzibar there are scarcity of learning and teaching materials especially in government schools which at eventually the outcomes of final results for the students are poorly, the other thing related to financial is on parents side, in Zanzibar people have low per capital income hence even the provision of the meat for the students when they are at school is unstable and it is obviously that pupils cannot learn and catch up materials well from their teachers while they are hungry hence leads to the post performance of the students in their financial examination compared to other countries where its people have at least stability 
economy and can take care of their children and motivate thus in good performance of their final exams.(The SACMEQ III projects in Zanzibari. A study of the conditions)

Curriculum problems; Tanzania curriculum and especially Zanzibar curriculum has not presities much technical's subjects and hand croft such as arts. Music, Architecture and Masons which could be helpful for the students after when they firms had up their studies and fail to continue with and level, this studies can give a chance for a graduate to self emplaced and earn his or her daily income but this curriculum of Zanzibar education gives much attention on other subjects which are theoretical oriented such as History, English social studies and Arabic therefore even after completion of studies most of graduates remain jobless and they haven't any extra curriculum skills, the only thing they posses is first the primary knowledge of social studies and Arts subjects which does not give them a chance to innovators or to employ themselves in a certain activities that could bring act an income. Also in this curriculum problem mathematics and science subjective are be included as a comport subject in all level of primary and education level but there are a huge scarcity of specialized teachers in those subjects, it sometimes it happened there to only one teacher of mathematics from standard one up to standard six this leads to insufficiency in trading a particular subjects hence pool performance of the indicated subject.

\section{Possible solutions}

Extensions of Educational budget in the government: the government of Zanzibar should extend the budget on educational sector's which will help to add and increase educational facilities such as buildings (classroom), books and other learning \& teaching materials.(Suckall, Tompkins, Stringer, 2014) Also to improve physical and social infrastructure for the succession of education or attainment, according to the National proclaimed policy of free education for pre - primary and primary education therefore there is the way that government could step aside from taking responsibility an Education development, due to the previously problems that has been analyzed in last papers it is time that Education in Zanzibar is still facing different problems and half of them is an that some of poor investment of financials in the Education, hence by increase 
the budget some problems like insufficiency of facilities, essence of meals in schools, absence of dormitories in the schools and poor infrastructures in school will end and the quality education will be provided and seen through final exams results.

Frequent upgrading of teacher's competence and improvements of their welfare. There should be an frequently upgrading of teachers competence so as to meet the current world of science and technology, that demands of purity graduates who can do something by their can and innovate new things through what they have learnt in school and applying in the real world, as it is seen that most of the teachers had the enough knowledge about the previously things but mostly of them does not know the demand of the current world, so the government should make sure that has program of upgrading teachers compliance in frequently so as to copy and match together with the demands of current world, Also apart from upgrading their competence the government though the ministry of financial affairs and education affairs must improve the teachers welfare and other motivations which will enhance them to teach effectively and dedicate all of their time in academic issues him the provision of quality education and better results of students in their final exams. Enhancing partnership with non governmental organizations (NGO's) in education development here the government of Zanzibar must be in a good condition on enhancing the partnership with NGO's which are dealing with educational development so as to have a wide room they see what other countries and international organizations have managed to improve the education sector and succeeded to produce graduators who are competitive in the world educational ranking and Employment market, also these NGO's should be keeping in touch with the government because they are always helping this sector through funding it through if giving act facilities like desks, books and books, but also these NGO's has managed to build different schools in Zanzibar and recruits qualified teachers from inside the country and from outside the country therefore if helps students of Zanzibar to receive quality education, exposure and attaining their education in conducive environment that support them hence the increases of performances in education. Putting emphasize on technical education \& science subjects. 
There should be a reshuffle or amendment in the curriculum on importing the technical subjects all level of comparison education, from primary to secondary level education, through inserting then in curriculum and putting emphasize on teaching these subject students will be able to employ themselves affair completed their studies and the increase the rate number of employed people in un official sectors such as commentary and Masons, but also the same emphasize should be placed in science subject, in Zanzibar science subjects are comparison in all level of comparison education, but the problem is there is poor emphasize and direct supervision on this subject if they are taught well as national exportations to have different scientific or otherwise, hence there are students who completed standard six but they don't know how to divide or to multiply numbers, therefore should be directly supervision and much emphasis to be imparted in these subjects so as to have graduates who are competent and innovators not theorists and politicians. Creations sophisticated policies that favors investors in education sector, the government of revolution of Zanzibar should are creating conducive and sophisticated policies that will favor and give ethnics for outside investors to see this islands it right place for people to come and building different schools for primary and secondary level and universities for the higher education level or to convince there to come up with their capitals or aids and direding to education sector hence improvements of this sector but all the these should be dome once there will be an conducive and sophisticate policies for them to come and invest in this sectors such of these policies or rules to be formulated to favor then like there will be no taxazations for any importations of schools facilities and learning materials from the development of the country, another done like there will be permission of citizenship and Non - conditional for a person group of people or company that will be invested in building the school or any academic institutional in Zanzibar, and the last policy or rule to be created so as to favor the investors is free sand position for a company or person who wants to establish. An academic institution, so through these suggestion the investors especially for outside the country will have a chance to see this place as a right place for their investments especially to education sector investments of parents in Education development and cost sharing the local government, school administration and parents should be in a right position in making sure that the education development is going well, since 
there is no successfully in any struggle that comes out of cooperation's between intruders, now the school has to make sure that parents of the children's are well informed about their children's development and what they suppose to help their children so as improve the performance of students in school, also the school must have good relationship with local government administration so as to make sure the school surroundings are safe and conducive for students to attain education, for example within the school compound or surrounding environment there should not be a club, Music, dancing hall or any activities that might doubt the academic activities in school, so this they did of local government is ensure the school surrounding is safe, also parents must be in touch with teachers so as to report the graduate change of behavior of their children so as they can cooperative together with teachers to suppress that behavior if it is bad and to motivate the specific behavior if it will be good one.

\section{Conclusion}

Generally the education situation in Zanzibar is still improving from one year to another and Zanzibar are now starting to see the important of education for children compared to last twenty years where by most of the parents did not considered education as important as much as in how they see it now days it should be noted that there is no permanent inheritance for children two their parents rather than education, therefore a lot of effort should be applied by the government NGO's in making sure that every Zanzibar child get a chance to attend the comparison education through media and other means of communications their parents should be informed well the important of education, since in some rural areas there are still a high rate of illiterate children especially Girls who are getting early marriage and skipping the school.

\section{Literatura}

1. Abdalla. S.M. (2014) Education statistical Abstract Ministry of Education and vocational training Zanzibar

2. Ignjatijević, S., Cogoljević, M., \& Milenković, N. (2018). Ekonomska ocena značaja obrazovanja u razvoju ekonomije zasnovane na znanju. Industrija, 46(3), 185-200.

3. Jovanović, N., \& Jovanović, M. (2018). Društveni faktori nejednakih šansi u obrazovanju. Godišnjak Pedagoškog fakulteta u Vranju, 9(1), 47-66. 
4. Hija, I. M. (2010) Zanzibar. International Encyclopedia of Education (Third Edition), 896-903

5. Kisić, S., \& Petković, S. (2019). Preduzetničko obrazovanje u funkciji razvoja veština za četvrtu industrijsku revoluciju. Ekonomika preduzeća, 67(1-2), 147-166.

6. MoEVT (2006) Zanzibar Education Policy. Ministry of Education and Vocational Training Zanzibar, 1-75.

7. MoEVT (2010). Various Education Reports. Zanzibar.

8. Stankić, R., Jovanović-Gavrilović, B., \& Soldić-Aleksić, J. (2018). Informaciono-komunikacione tehnologije u obrazovanju kao podsticaj ekonomskom razvoju. Ekonomski horizonti, 20(1), 61-73.

9. Suckall, N., Tompkins, E., Stringer, L. (2014). Identifying trade-offs between adaptation, mitigation and development in community responses to climate and socio-economic stresses: Evidence from Zanzibar, Tanzania, Applied Geography, 46(1), 111-121.

10. The SACMEQ III projects in Zanzibari. A study of the conditions.

\title{
OBRAZOVNA SITUACIJA U ZANZIBARU
}

\section{Ramadhani Issa Hemed ${ }^{2}$}

\begin{abstract}
Ovaj rad prikazuje obrazovnu situaciju u Zanzibar, ubrzo nakon dostizavanja nezavisnosti, ovaj članak je podeljen na dva dela, prvi deo je diskutovanje o istorijskoj pozadini obrazovnog sistema pre i različitih koraka koje je obrazovni sektor dostigao do godine 2018. godine, a on će pokušati da ilustruje obrazovnu strukturu Zanzibar sa svojim motivima za Zanzibaris i nacionalni razvoj.

Na kraju postoji drugi deo koji govori o nekim najuobičajnijim pitanjima koja su od vitalnog značaja za raspravu o obrazovnoj situaciji u Zanzibaru, kao što je upis učenika na oba nivoa obrazovanja, društveno-ekonomskog konteksta, kvaliteta i efikasnosti obrazovanja u društvu, škole, kvalitet ljudskih resursa $i$ infrastrukturu, finansiranje i konačno pristup obrazovanju.

Posle razgovora o ovim pitanjima ovaj rad iznova razmatra poboljšanja $i$ pridnosti u oblasti obrazovanja Zanzibara, u poređenju sa drugim zemljama $u$
\end{abstract}

\footnotetext{
${ }^{2}$ Ramadan Issa Hemed, becelor, Univerzitet u Der es Salam, Tanzania, Mwalimu Julius Nyerere Mlimani Campus, P.O. Box 35091, Dar es Salaam Tanzania, ramahchonde2794@gmail.com
} 
istočnoj Africi, izazovi sa kojima se suočava Zanzibar i sugestiju na razmatrane probleme.

Ključne reči: obrazovanje, Zanzibar, ekonomija javnog sektora

JEL: $A 20$

Datum prijema (Date recieved): 12.02.2019.

Datum prihvatanja (Date accepted): 30.03.2019. 